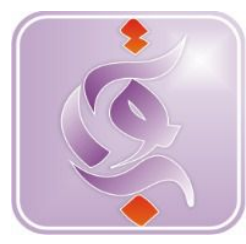

\title{
GAMBARAN STRES KERJA PADA POLISI WANITA DI KEPOLISIAN RESOR KOTA PADANG
}

Received: $27^{\text {th }}$ December 2017; Revised: $11^{\text {th }}$ January 2018; Accepted: $30^{\text {th }}$ February 2018

\author{
Nur'Aisyiah Yusri \\ UIN Imam Bonjol Padang \\ Email: nuraisyiah@uinib.ac.id \\ Mutia Farida \\ UIN Alauddin Makassar
}

\begin{abstract}
Abstrak: Polisi wanita memiliki tugas dan tanggung jawab yang sama dengan polisi laki laki sebagian waktunya dihabiskan di tempat kerja, tuntutan untuk meluangkan waktu bersama keluarga tidak terpenuhi, maka hal ini akan menimbulkan konflik peran ganda dan stres kerja berpengaruh signifikan terhadap keharmonisan keluarga. Penelitian ini menjelaskan bahwa kondisi stres didiagnosa berdasarkan 3 jenis gejala yaitu gejala fisik, perilaku, dan tempat kerja, dimana gejala-gejala tersebut dapat membuat individu waspada terhadap kenyataan bahwa berada di bawah pengaruh stres yang mempengaruhi kehidupannya. Tujuan penelitian ini adalah untuk menguji ada atau tidaknya stres kerja pada polisi wanita di kepolisian resor kota Padang". Metode yang digunakan kuantitatif dengan teknik analisis data yaitu analisis korelasi Pearson. Populasi penelitian yakni polisi wanita yang bertugas di kepolisian resor kota Padang dengan ketentuan yang sudah menikah yang berjumlah 48 orang. Sampel pengumpulan data dalam penelitian ini menggunakan skala gejala stres kerja.

Hasil analisis data penelitian menunjukkan stres kerja polisi wanita kepolisian resor kota Padang memiliki tingkat stres kerja yang rendah yaitu sebesar $2 \%$.
\end{abstract}

Kata Kunci : Stres kerja, polisi wanita.

\section{LATAR BELAKANG}

Organisasi menghendaki adanya tujuan yang ingin dicapai dengan melakukan berbagai usaha dan aktivitas melalui beberapa pendekatan untuk mencapai hasil yang maksimal dan optimal. Faktor manusia merupakan variabel yang sangat penting karena berhasil atau tidaknya suatu usaha sebagian besar ditentukan oleh karyawan. Sumber daya manusia (SDM) merupakan aset utama yang sangat besar pengaruhnya terhadap kemajuan perusahaan. Harrisma dalam Wuisan (2007:128) mendefinisikan sumber daya manusia adalah unsur yang sangat menentukan dalam aktifitas suatu perusahaan. Sumber daya manusia dalam sebuah organisasi merupakan sebuah aset yang paling berharga sehingga perlu dikelola secara baik dan profesional agar dapat tercipta keseimbangan antara kebutuhan sumber daya manusia dengan tuntutan pencapaian organisasi.

Kualitas sumber daya manusia dengan memperhatikan karyawan terutama segala kebutuhannya dalam pencapaian hasil atau output yang maksimal dan berkualitas. Masalah yang muncul baik internal dan eksternal, adapun masalah internal seperti kesehatan yang tidak baik, kurangnya istirahat, maupun emosi yang tidak terkontrol. Sedangkan masalah eksternal seperti pekerjaan yang menumpuk, adanya 
tekanan di tempat kerja, kurangnya rasa nyaman di tempat bekerja, karena hal ini akan mempengaruhi cara kerja karyawan dalam bekerja.

Salah satu bentuk tekanan di tempat kerja adalah stres. Secara sederhana stres merupakan suatu bentuk tanggapan seseorang baik secara fisik maupun mental terhadap suatu perubahan di lingkungannya yang dirasakan mengganggu dan mengakibatkan dirinya terancam (Anoraga, 2014:108). Stres yang dialami karyawan dalam organisasi muncul karena adanya sikap karyawan dalam proses menyelesaikan pekerjaannya dikarenakan karyawan mengalami gangguan baik secara fisik maupun secara psikologis yang berlebihan.

\section{TUJUAN}

Adapun tujuan tulisan ini adalah untuk mengetahui tingkat stres kerja polisi wanita di kepolisian resor kota Padang.

\section{KAJIAN TEORI}

Salah satu bentuk tekanan di tempat kerja adalah stres. Secara sederhana stres merupakan suatu bentuk tanggapan seseorang baik secara fisik maupun mental terhadap suatu perubahan di lingkungannya yang dirasakan mengganggu dan mengakibatkan dirinya terancam (Anoraga, 2014:108). Stres yang dialami karyawan dalam organisasi muncul karena adanya sikap karyawan dalam proses menyelesaikan pekerjaannya dikarenakan karyawan mengalami gangguan baik secara fisik maupun secara psikologis yang berlebihan.

Stres kerja bagian dari stres kehidupan, dan kepuasan kerja sebagian dari kepuasan dalam kehidupan. Stres yang begitu hebat yang melampaui batas-batas toleransi akan berkaitan langsung dengan gangguan psikis dan ketidakmampuan fisik. Harrisma dalam Luthans (2013:650) mendefinisikan stres kerja sebagai respon adaptif atau suatu cara menyesuaikan diri dengan keadaan sekitar yang dihubungkan dengan perbedaan individu atau proses yang merupakan tuntutan psikologi atau fisik yang berlebihan pada seseorang.
Karyawan yang mengalami stres di lingkungan kerjanya dapat memengaruhi kemampuan karyawan tersebut dalam bekerja. Salah satu alasan mengapa stres perlu untuk dibahas adalah orang yang stres tidak dapat bekerja secara optimal sehingga akan memberi dampak negatif pada hasil kerjanya dan juga dalam lingkungan sosialnya.

Menurut Ali dalam Mahmudah (2009:213), perempuan dianggap lebih rendah dari laki-laki, tidak cocok menduduki suatu kekuasaan ataupun memiliki kemampuan yang setara dengan laki-laki. Hak perempuan dibatasi di rumah dan di dapur, rutinitas kegiatannya hanya di sekitar rumah dan dianggap tidak mampu mengambil keputusan di luar wilayahnya. Seiring dengan kemajuan teknologi dan semakin berkembangnya masyarakat, kaum wanita sudah seharusnya tidak memiliki hambatan lagi untuk terampil dalam memasuki berbagai bidang profesi dan bekerja di luar rumah membantu perekonomian keluarga saat ini. Semakin besar jumlah wanita yang bekerja dan semakin banyak wanita yang berhasil memasuki jenis-jenis pekerjaan yang selama ini belum pernah dimasuki kaum hawa.

Secara langsung fenomena itu dapat dilihat banyak wanita telah menduduki posisi top manager dan bahkan sampai pada direktur eksekutif, bertebaran diberbagai sektor usaha, sektor industri konstruksi, farmasi, bahkan profesi tergolong keras seperti anggota militer bahkan kepolisian (Anoraga, 2014:140).

Wanita yang berprofesi sebagai polisi bertugas untuk mengayomi masyarakat, melakukan operasi pengamanan sindikat narkoba, razia bagi pengguna jalan yang kurang tertib, penertiban jalur lalu lintas, melakukan pengawasan eksekusi tanah sengketa yang bertentangan dengan massa, serta melakukan pengawasan dan penjagaan apabila adanya kunjungan tamu dari luar daerah yang seharusnya pekerjaan ini dilakukan oleh laki-laki tetapi kenyataannya wanitalah yang melakukan. Karena tidak ada perbedaan tugas antara polisi laki-laki 
dan polisi wanita yang telah menjadi tugas serta kewajiban sebagai anggota kepolisian.

Hasil wawancara dengan Kasubag Pers Polresta Padang bahwa, sebagai polisi wanita (polwan) yang bekerja di luar kantor atau di lapangan seperti razia di tempat hiburan malam, melakukan operasi pengguna narkoba, melakukan pengamanan bagi geng motor, dan mengamankan siswa yang melakukan tawuran, pengawasan di persimpangan jalan dan lampu merah untuk menertibkan lalu lintas, karena itu mereka sering dihadapkan pada situasi genting yang dapat mengancam keselamatan mereka. Tidak jarang mereka dihadapkan pada cuaca yang begitu terik dan juga hujan, yang berdampak pada kesehatan mereka. Selain dihadapkan pada tempat kerja yang kurang kondusif dan jam kerja yang tinggi, mereka harus meninggalkan keluarga demi tugas.

Meski demikian mereka telah mengambil resiko yang menuntut mereka menghabiskan banyak waktu di tempat kerja dibanding berkumpul dengan keluarga. Instansi telah menetapkan waktu kerja yang berlaku pukul 08.00 - 14.00 WIB terhitung dari hari senin hingga kamis, hari jum'at pukul 08.00 - 11.00 WIB dan hari sabtu mulai pukul 08.00 - 13.00 WIB. Bekerja 6 hari dengan sistem pelayanan 24 jam, mulai patroli di malam hari hingga apel pagi selesai. Mengorbankan keluarga demi mengayomi dan melindungi masyarakat mereka lakukan, bahkan kurangnya waktu yang berkualitas untuk berkumpul dengan keluarga. Serta berbagai macam tuntutan yang mengharuskan mereka lebih banyak menghabiskan waktu di tempat kerja (Wawancara kabag Sumda Polresta Padang, Jum'at 17/03/2017).

Sebagai seorang polwan dituntut harus multitalent (multi fungsi) dalam menjalankan tugas dan kehidupan sehari-hari. Sebagai seorang wanita pekerja dan ibu rumah tangga, dituntut sama dalam bertugas dengan polisi laki-laki baik di lapangan seperti menjadi penyidik, menggrebek tempat kejahatan, ada yang menjadi negosiator pada saat demo, menjaga lalu lintas maupun staf dan lainnya. Semua tugas sebagai anggota polisi maupun seorang ibu rumah tangga dijalani dengan penuh tanggung jawab dan profesional.

Begitu banyak tuntutan yang mesti dilaksanakan seorang polwan, bahkan dapat mengancam keselamatan diri mereka, seperti luka-luka dan tewas saat menjalani tugas, banyaknya musuh terutama para pelaku kejahatan. Stres yang polwan rasakan juga disebabkan tidak bisa libur seperti pegawai lain, tidak peduli tanggal merah, bahkan cuti bersama. Dimana saat seperti itulah waktu untuk dapat berkumpul dengan keluarga besar, tetapi bagi polwan keamanan dan pengamanan tidak mengenal hari libur. Maka dari itu seorang polisi tidak memiliki jadwal libur yang sama dengan pegawai lainnya, selain itu polisi juga tidak bisa mudik sebab harus menjaga wilayah agar tetap aman Sari dalam Rahajo (17:2015). Selain melaksanakan tugas, polwan harus rela hidup berjauhan dengan keluarga, karena mendapat penugasan di luar kota yang mengharuskan mereka para polisi untuk siap di tugaskan dimana saja. Polisi harus siap siaga 24 jam jika keadaan darurat menuntut mereka bekerja pagi, siang, dan malam hari.

Menurut Anoraga (2014:121), bagi wanita pekerja bagaimanapun juga mereka adalah ibu rumah tangga yang sulit lepas begitu saja dari lingkungan keluarga, karena wanita mempunyai beban dan hambatan lebih berat dibanding rekan prianya, dalam arti wanita harus lebih dahulu mengatasi urusan keluarga, suami, anak dan hal-hal lain yang menyangkut rumah tangga. Polwan dihadapkan pada peran ganda sebagai wanita bekerja dan sebagai ibu rumah tangga. Proses pembagian peran dapat menyebabkan ketidakseimbangan peran atau terjadi proses peran satu (sebagai ibu rumah tangga) mencampuri peran yang lain (sebagai wanita pekerja) yang apabila terjadi terus-menerus dengan intensitas yang kuat dapat menyebabkan konflik 
Nur'Aisyiah Yusri, Mutia Farida, Gambaran Stres Kerja ... 75

Yusnita dalam (Kussudyarsana dan

Soepatini, 2008: 3).

Menurut Martaniah dalam Hartati

(2000:2) dalam meniti karir wanita mempunyai beban lebih dibanding rekan prianya, wanita terlebih dulu harus mengatasi urusan keluarga dan hal-hal yang menyangkut rumah tangga, kedua peran ini dijalani dalam waktu bersamaan. Dampak dari peran ganda adalah berkurangnya waktu dan perhatian terhadap suami dan anak-anak, ibu yang bekerja di luar rumah dianggap kurang berperan secara emosional dan kurang menyediakan waktu dalam pengasuhan anak. Masalah lainnya yang muncul adalah pengaturan waktu, stres dan kelelahan.

Tuntutan peran sebagai ibu rumah tangga membuat wanita harus lebih banyak memberikan perhatian kepada anak, suami dan orang tua. Di sisi lain tuntutan karir memberikan kesempatan yang luas bagi wanita untuk mengembangkan dirinya pada pekerjaan sehingga menjanjikan perolehan jabatan (posisi) yang lebih baik ataupun pendapatan yang lebih besar. Proses pembagian peran wanita dapat menyebabkan ketidak seimbangan peran antara sebagai ibu rumah tangga dan sebagai wanita pekerja (Yusnita dalam Ruderman, 2002:2).

\section{GEJALA-GEJALA STRES}

Stres adalah kondisi yang memicu stres pada orang lain. Ananta \& Ellitan (2009:71) menerangkan, stres yang dialami individu dalam lingkungan kerjanya sering kali dipicu oleh hal-hal yang berasal dari dalam individu (internal) dan dari luar (eksternal) yang membawa konsekuensi berbeda bagi masing-masing individu tergantung bagaimana mereka merespon penyebab stres.

Stres mempengaruhi baik pada fisik maupun proses mental dan nantinya, keduanya akan mempengaruhi bagaimana berperilaku di bawah tekanan yang berat, dan mempengaruhi tingkatan di mana bisa melanjutkan peran di rumah dan di tempat kerja secara efektif dan efisien. Dhania dalam Baron (2000:230) menjelaskan bahwa kondisi stres didiagnosa berdasarkan 3 jenis gejala yaitu gejala fisik, perilaku, dan tempat kerja, dimana gejala-gejala tersebut dapat membuat waspada terhadap kenyataan bahwa kita berada di bawah pengaruh stres.

\section{Gejala Fisik}

Nafas menjadi semakin cepat, mulut dan kerongkongan kering, kedua tangan menjadi basah oleh keringat, tubuh merasa gerah, otot-otot menjadi tegang, tubuh mengalami gangguan pencernaan, diare, sembelit, badan terasa lelah, kepala menjadi sakit dan tegang, berkedut (kejang-kejang atau bergetarnya urat-urat pada kelopak mata, kadang dianggap sebagai pertanda atau firasat akan terjadinya sesuatu, dan perasaan sangat gelisah). Tentu saja, gejala seperti ini dapat dialami dalam kehidupan normal sebagai akibat gerak fisik yang biasa. Semua itu menjadi gejala stres apabila tidak ada penyebabnya dan beberapa diantaranya muncul pada saat yang sama atau saat kita mengalaminya lebih sering daripada yang kita harapkan.

\section{Gejala Perilaku}

a. Perasaan terganggu, khawatir, sedih, salah paham, tidak berdaya, tidak mampu mengatasi persoalan yang dihadapi, gelisah, merasa gagal, tidak termotivasi untuk bekerja.

b. Kesulitan berkosentrasi, berpikir jernih, membuat keputusan.

c. Hilangnya kreativitas bekerja, minat terhadap orang lain.

Mengenali cara seperti itu, baik yang ada dalam diri sendiri maupun di dalam diri orang lain, tanpa menyadari bagaimana stres mempengaruhi kita. Merasa kecewa, marah dan canggung, atau sebentar-sebentar terbangun di malam hari karena memikirkan pekerjaan. Mendapatkan kesulitan untuk berkonsentrasi, untuk berpikir secara jernih, atau untuk mengambil keputusan, atau mengalami kehilangan kreativitas dan semakin kurang perhatian terhadap diri sendiri maupun terhadap orang lain. 


\section{Gejala di tempat kerja}

Kita menghabiskan waktu dari sebagian besar hidup kita ketika berada di tempat kerja. Apabila terkena stres, gejalagejala itu dapat mempengaruhi kita di tempat kerja dan sering kali melalui cara sebagai berikut: menurunnya kepuasan kerja, menurunnya kinerja, hilangnya semangat dan energi, komunikasi yang tidak lancar, buruknya pengambilan keputusan, berkurangnya kreativitas dan inovasi, dan terfokusnya perhatian ke tugas-tugas yang justru tidak produktif.

Dengan mengenali dan mengakui semua perubahan ini, kita dapat mencegah sekurang-kurangnya sebagian dari akibatakibat stres dalam jangka waktu yang lebih lama dalam berperilaku di tempat kerja, akibat ini dapat dilihat melalui kesehatan, prestasi dan produktivitas seseorang.

\section{METODE}

Pendekatan yang digunakan dalam penelitian ini adalah pendekatan penelitian kuantitatif, yang menekankan analisisnya pada data-data numerikal (angka), yang diolah dengan metode statistika (Azwar, 2010:5).

\section{SKALA STRES KERJA}

Skala yang digunakan adalah skala yang peneliti susun sendiri melalu persetujuan profesional judgment Skala ini disusun oleh penulis mengacu pada aspek stres kerja yang terdiri dari gejala fisik, gejala perilaku, gejala di tempat kerja. Pengukuran skala bertujuan untuk mengetahui tingkat stres kerja yang dialami oleh polwan di kepolisian resor kota Padang. Kemudian 3 aspek stres kerja ini dijabarkan dalam 31 aitem pernyataan. subjek penelitian yang diteliti sebanyak 48 orang

\section{HASIL PENELITIAN}

Kategorisasi dari tingkat stres kerja memperlihatkan bahwa rata-rata polwan di kepolisian resor kota Padang dikategorisasikan berdasakan mean ideal dengan alasan untuk menyeimbangkan subjek dibagi dua yaitu rendah, dan tinggi, dengan rumus:

$$
\mathbf{I}=\underline{\mathbf{R}}
$$

Keterangan:

$\mathrm{I}=$ Interval

$\mathrm{R}=$ Range (nilai tertinggi-nilai terendah)

$\mathrm{K}=$ Kelas Interval (tinggi dan rendah)

$\mathrm{I}=79-57 / 2=11$

Jadi, nilai I (Interval) adalah 11 maka untuk pengkategoriannya:

\section{Tabel 1}

Kategorisasi berdasarkan skala stres kerja

\begin{tabular}{lllll}
\hline N & Sko & Ju & Kateg \\
o & r & $\begin{array}{l}\text { ml } \\
\text { ah }\end{array}$ & $\begin{array}{l}\text { Pers } \\
\text { onta } \\
\text { se }\end{array}$ \\
& & & & \\
\hline 1 & $57-$ & 47 & $\begin{array}{l}\text { Renda } \\
\text { h }\end{array}$ & $\begin{array}{l}98 \\
\end{array}$ \\
& 68 & & r
\end{tabular}

$\begin{array}{lllll}6 & 69- & 1 & \text { Tinggi } & 2 \% \\ 79 & & \end{array}$

Sumber : Data Penlitian

Berdasarkan tabel 1 didapatkan bahwa 48 orang subjek yang diteliti sebanyak 47 orang atau sebesar 98\% memiliki tingkat stres kerja yang rendah, sebanyak 1 orang atau sebesar $2 \%$ memiliki tingkat stres kerja yang tinggi. Dari besaran persentase stres kerja pada tabel tersebut, menunjukkan bahwa polisi wanita di kepolisian resor kota Padang memiliki tingkat stres kerja yang dikategorikan rendah.

Tabel 2 
Nur'Aisyiah Yusri, Mutia Farida, Gambaran Stres Kerja .... 77

\section{Uji normalitas sebaran skala stres kerja}

\begin{tabular}{cc}
\hline & stres kerja \\
\cline { 2 - 2 } $\begin{array}{c}\text { Kolmogorov- } \\
\text { Smirnov Z }\end{array}$ & 0.960 \\
$\begin{array}{c}\text { Asymp. Sig. } \\
\text { (2-tailed) }\end{array}$ & 0.316 \\
\hline
\end{tabular}

a. Test distribution is Normal.

b. Calculated from data.

Dari analisis data yang diperoleh, menunjukkan bahwa didapatkan data dari 48 orang subjek yang diteliti, sebanyak 1 orang atau sebesar $2 \%$ memiliki tingkat stres kerja yang tinggi, dan sebanyak 47 orang atau sebesar 98\% memiliki tingkat stres kerja yang rendah.

Kondisi stres didiagnosa berdasarkan 3 jenis gejala yaitu gejala fisik, perilaku, dan tempat kerja, dimana gejala-gejala tersebut dapat membuat kita waspada terhadap kenyataan bahwa kita berada di bawah pengaruh stres. Gejala fisik yang dialami polwan seperti otot-otot menjadi tegang, tubuh mengalami gangguan pencernaan, diare, sembelit, badan terasa lelah, kepala menjadi sakit dan tegang, sedangkan gejala perilaku dapat dilihat seperti kesulitan berkosentrasi, berpikir jernih, membuat keputusan, hilangnya kreativitas bekerja, minat terhadap orang lain. Kemudian gejala di tempat kerja seperti menurunnya kepuasan kerja, menurunnya kinerja, hilangnya semangat dan energi, komunikasi yang tidak lancar, buruknya pengambilan keputusan, berkurangnya kreativitas dan inovasi.

\section{PENUTUP}

Polisi wanita di Kepolisian Resor Kota Padang memiliki tingkat stres kerja yang rendah sebanyak 47 orang atau sebesar $98 \%$ dan sebanyak 1 orang atau sebesar $2 \%$, memiliki tingkat stres kerja yang tinggi. Artinya adalah Polisi wanita di kepolisian resor kota Padang memiliki tingkat stres kerja yang rendah.
Anoraga, Panji. (2014). Psikologi Kerja, Jakarta : PT Rineka Cipta.

Azwar, Saifuddin. (2010). Penyusunan Skala Psikologi. Yogyakarta: Pustaka Belajar.

Basri, H. (1996). Keluarga Sakinah Tinjauan Psikologi Dan Agama. Yogakarta: Pustaka Pelajar.

Chaplin, James P.(2005). Kamus Lengkap Psikologi. Jakarta: PT Raja Grafindo Persada (Fajar Interpratama Offset).

Cooper, Cary \& Alison Straw. (2002). Stres manajemen yang sukses dalam sepekan (Sugeng Panut, Penerjemah). Jakarta: Kesaint Blanc.

Dagum , Drs. Save M. (2013). Psikologi Keluarga. Jakarta: PT Rineka Cipta

Darajat, Zakiah. (1984). Islam dan peranan wanita, Jakarta : Bulan Bintang.

Dhania, Dhini Rama. (2010). Pengaruh stres kerja, beban kerja terhadap kepuasan kerja. Jurnal Psikologi; Vol 01 (01).

Engineer, Asghar Ali. (1994). Hak-hak perempuan dalam islam, terj. Farid Wajidi dan Cici Farkhan Asegaf, Yogyakarta: Yayasan Benteng Budaya.

Gunarsa, D. (2012) .Psikologi Keluarga, Jakarta : PT BPK Gunung Mulia.

Harisman, Okta Wisudawati dan Wijaksono, Andre Dwijanto. (2013). Pengaruh Stres Kerja Terhadap Produktivitas Kerja Melalui Kepuasan Kerja Jurnal Ilmu Manajemen.

Mahmudah, Siti. (2012). Peran wanita dalam menciptakan keluarga sakinah. Jurnal Psikologi.

Mubarok, Achmad . (2016). Psikologi keluarga. Malang: Madani.

Munandar, Ashar Sunyoto. (2001). Psikologi Industri dan Organisasi. Jakarta: UIPress.

Pena, Tim Prima. 2010. Kamus Besar Bahasa Indonesia: Gita Gramedia Press

Priyatno, Duwi. 2012. SPSS 20: Belajar Cepat mengolah Data Statistik dengan SPSS. Yogyakarta: C.V Andi Offset

Ratnawati, Peni. Keharmonisan Keluarga 
Antara Suami Istri Ditinjau dari Kematangan Emosi Pada Pernikahan Usia Dini. Jurnal Psikologi Universitas Semarang

Samosir, Zurni Zahara dan Syahfitri Iin. (2006). Faktor penyebab stres kerja pustakawan pada perpustakaan Universitas Sumatera Utara. Jurnal Studi Pustaka dan Informasi.Vol04 (02).

Sari, Ririn Wedya Putri Mayang dan Ahmad Mardalis. (2015). Pengaruh Konflik Peran Ganda Dan Stres Kerja Terhadap Kinerja Polisi Wanita Di Polresta Surakarta. Naskah Publikasi Program Studi Manajemen Fakultas
Ekonomi Dan Bisnis Universitas Muhammadiyah Surakarta

Wijono, Sutarto.( 2010). Psikologi Industri dan Organisasi dalam suatu bidang gerak. Jakarta: Kencana.

Tirtawinata, Christofora Megawati. (2013).

$$
\text { Mengupayakan Keluarga }
$$
yang Harmonis. Kemanggisan Jakarta Barat. Vol 04 (02).

Yusnita,Tri Rita. (2010). Pengaruh Pengembangan Karier Terhadap Konflik Pekerjaan Keluarga Dan Ketakutan Akan Kesuksesan Pada Wanita Serta Dampaknya Pada Prestasi Kerja. Jurnal Psikologi.. 